\title{
New distribution records of kelp in the Kitikmeot Region, Northwest Passage, Canada, fill a pan-Arctic gap
}

\author{
Bodil A. Bluhm ${ }^{1}$ (1) $\cdot$ Kristina Brown ${ }^{2} \cdot$ Lina Rotermund ${ }^{2} \cdot$ William Williams $^{2} \cdot$ Seth Danielsen $^{3} \cdot$ Eddy C. Carmack $^{2}$
}

Received: 1 June 2021 / Revised: 21 December 2021 / Accepted: 10 January 2022 / Published online: 1 March 2022

(c) The Author(s) 2022

\begin{abstract}
Kelps play important roles in ecosystems as they provide structural habitat and protection, and supply food. Given these beneficial roles and observed increases in seaweed biomass and distribution ranges across the Arctic, mapping kelp occurrence around Arctic coasts is both timely and necessary for future conservation. Here, we fill spatial gaps in the knowledge of kelp distribution in the southern Northwest Passage, Canadian Arctic Archipelago; specifically, we report the occurrence of Laminaria solidungula, Saccharina latissima and Alaria esculenta from Victoria and Dease straits and Bathurst Inlet in the Kitikmeot Region at depths mostly from 10 to $30 \mathrm{~m}$ (max. $40 \mathrm{~m}$; upper extent vessel-limited). Kelp specimens were found at bottom water temperatures from sub-zero to $1{ }^{\circ} \mathrm{C}$ (surface-T to $\sim 6^{\circ} \mathrm{C}$ ) and bottom water salinities of $\sim 28$ (surface$\mathrm{S}<20$ ) in August-September. Kelp sites were characterized by both strong tidal currents (max. estimates from a tidal model $20-70 \mathrm{~cm} \mathrm{~s}^{-1}$ in center of passages) and hard substrates, interspersed with finer sediments. Co-occurring identifiable epibenthos was dominated by suspension-feeders preferring currents (sea cucumbers, soft corals, Hiatella clams), potential kelp consumers (sea urchins Strongylocentrotus sp., Margarites snails, limpets) and predatory invertebrates (sea stars, lyre crabs). At the same and some deeper nearby sites, loose kelp fragments were also found at the seabed, suggesting that kelps contribute to the regional detrital food web by supplying carbon to less productive sites. Kelps in the region may expand their ranges and/or growing season with reduced ice cover and warming, although constraints through local turbidity sources, extreme temperatures, low salinity and low nutrient concentrations are also recognized.
\end{abstract}

Keywords Arctic $\cdot$ Kelp $\cdot$ Alaria esculenta $\cdot$ Laminaria solidungula $\cdot$ Saccharina latissima $\cdot$ Northwest Passage $\cdot$ Habitat

\section{Introduction}

Kelps, which are large brown seaweeds in the order Laminariales, play many important roles in marine socio-ecosystems. Kelp systems are a prominent feature of temperate and high latitude rocky coasts (Wiencke and Amsler 2012, Filbee-Dexter et al. 2019) and are characterized as biomass-rich and diverse structural biotopes (Steneck et al. 2002). They provide a living habitat for many other species, for example: numerous crustaceans and polychaetes

Bodil A. Bluhm

bodil.bluhm@uit.no

1 Institute of Arctic and Marine Biology, UiT - The Arctic University of Norway, Troms $\varnothing$, Norway

2 Fisheries and Oceans Canada, Sidney, BC, Canada

3 College of Fisheries and Ocean Sciences, University of Alaska Fairbanks, Fairbanks, AK, USA live inside kelp holdfasts (Schuster and Konar 2014); diatoms, bryozoans, hydrozoans are epiphytic on kelp blades (Forbord et al. 2020); sea urchins directly ingest kelp, while predatory crabs and other invertebrates use kelp systems as habitat (Konar and Estes 2003). Kelp systems also serve as important habitat for certain fishes, including commercial species such as cod, herring and rockfish at high latitudes (Norderhaug et al. 2005; Costa et al. 2020). In addition to the structural roles (habitat and shelter), kelps are part of the food web both directly as a food source for kelp grazers (Norderhaug and Christie 2009), and indirectly as detrital material. In form of detritus, kelp can be distributed to regions much farther from, and deeper than, their growth sites (Krumhansl and Scheibling 2012; Pedersen et al. 2020). Kelps and other seaweeds also provide a food source to humans and livestock through in situ harvests (Makkar et al. 2016) as well as increasingly through ocean farming, even at high latitudes (Forbord et al. 2020). Finally, as large and fast-growing primary producers with high productivity 
rates (Krause-Jensen et al. 2012), kelps along with other macroalgae, can sequester and store substantial amounts of atmospheric $\mathrm{CO}_{2}$ (Chung et al. 2011). As a consequence of these various functions, these seaweeds play a role in conservation planning of kelp systems (Costa et al. 2020 and references therein) and blue carbon strategies (KrauseJensen et al. 2018). Recent comprehensive compilations of pan-Arctic kelp and other macroalgal data sets show that in many remote Arctic regions including the Canadian Arctic the extent of kelp distribution mapping shows large gaps (Filbee-Dexter et al. 2019; Krause-Jensen et al. 2020).

The occurrence of kelps and other seaweeds is constrained by a combination of environmental factors, some of which display more extreme seasonality in the Arctic marine system than found in boreal regions (see Johnsen et al. 2020 for a summary). Long periods of darkness limit photosynthesis, winter temperatures at or near freezing affect metabolism, and sea-ice scour of the seafloor cause mechanical disturbance, rendering many shallow areas uninhabitable for most macroalgae (Fredriksen et al. 2019). As an adaptive measure, however, the minimum light requirement for growth, photosynthesis and completing the life cycle tends to be particularly low for polar species, and the tolerance of long dark periods is particularly high (Wiencke and Amsler 2012). Low temperatures are tolerated in particular by typical Arctic species such as the endemic kelp Laminaria solidungula while boreal species extending into the Arctic were thought to have higher growth optima (tom Dieck (Bartsch) 1992). Challenging this paradigm, however, Bringloe et al. (2020) recently proposed that Arctic macroalgae communities are in fact adapted to Arctic conditions rather than merely tolerating them since, so they argue, they persisted through glaciations. Seasonally and diurnally low salinities due to large amounts of freshwater run-off and ice melt at Arctic coasts in general (Carmack et al. 2016), and in the study area in particular (Williams et al. 2018) require osmotic adaptation, generally found in intertidal macroalgae (Karsten et al. 1991), while subtidal habitats are less variable and subtidal kelps may thus be comparatively less adapted (Johnsen et al. 2020). The requirement for hard substrate for attachment further constrains distributions around the Arctic (see Lantuit et al. 2012 for coastal classification) resulting in seaweeds being most widespread in Arctic Norway, Canada and Greenland in addition to various island groups and small patches of boulders (Wilce and Dunton 2014; Filbee-Dexter et al. 2019; Krause-Jensen et al. 2020). Despite the extreme Arctic conditions, Wilce (1994) reported that upwards of 150 species of largely widespread macroalgae have successfully colonized in Arctic waters, and Fredriksen et al. (2019) reported 197 species in a recent survey in Svalbard waters. Archambault et al. (2010) estimated 210 macroalgal species for the Canadian Arctic. While less than a dozen are kelp species (order Laminariales), including the Arctic endemic
Laminaria solidungula as well as widespread kelps in the genera Saccharina and Alaria (Wilce and Dunton 2014; Filbee-Dexter et al. 2019), these kelps are often the biomass dominant macroalgae in the subtidal due to their large size (Johnsen et al. 2020).

Given the ecological and emerging economic role of kelps in high latitudes in general, and the coastal Arctic in particular, mapping their distribution and the biological communities they support or are associated with has been showcased as both urgent and critical (Filbee-Dexter et al. 2019). In addition, kelp and other macroalgae have been increasing in extent and biomass across the Arctic (and decreasing at southern boundaries), and/or depth distributions have shifted over the past decades in response to decreasing sea ice cover (Kortsch et al. 2012, Krause-Jensen et al. 2020), yet regional knowledge on their distribution is incomplete. A recent, pan-Arctic compilation of kelp distributions provides a comprehensive status overview (Filbee-Dexter et al. 2019). In this compilation, Arctic Canada was identified as one of the areas with the most extensive gaps in mappings of pan-Arctic kelp distributions. As the Northwest Passage in particular is increasingly being used by vessel traffic (Silber and Adams 2019) a baseline of habitat types is much needed. To address these needs, here we present new records of several kelp species from the Kitikmeot Region of the southern Northwest Passage in the Canadian Arctic Archipelago in a small-scale survey. We further characterize relevant habitat and oceanographic conditions (substrate, temperature, salinity, nutrient concentrations and irradiance) where these species were found, and speculate how kelps may fare under changing environmental conditions in the area.

\section{Methods}

\section{Study area}

Sampling was conducted onboard the R/V Martin Bergmann in the Kitikmeot Region of the southern Northwest Passage between Bathurst Inlet to the west and Victoria Strait to the east $\left(66.8-69.0^{\circ} \mathrm{N}, 101.8-108.1^{\circ} \mathrm{W}\right.$, Fig. 1$)$ from 11 to 15 August 2016, 23-29 August 2017 and 19 August-5 September 2019. Survey depths ranged between 10 and $93 \mathrm{~m}$. The Kitikmeot Region in Canada's Nunavut Territory comprises Coronation Gulf and Bathurst Inlet to the west and Queen Maud Gulf and Chantrey Inlet to the east, connected through Dease Strait in the center (Fig. 1). The study area is an oceanographically unique part of the Canadian Arctic Archipelago due to its massive freshwater input relative to the area's size (Brown et al. 2020), and its shallow $(<30 \mathrm{~m})$ bounding sills at Dolphin-Union (west) and Victoria straits (to the northeast) that constrain surface outflows of low salinity waters and sub-surface inflows of more saline waters 

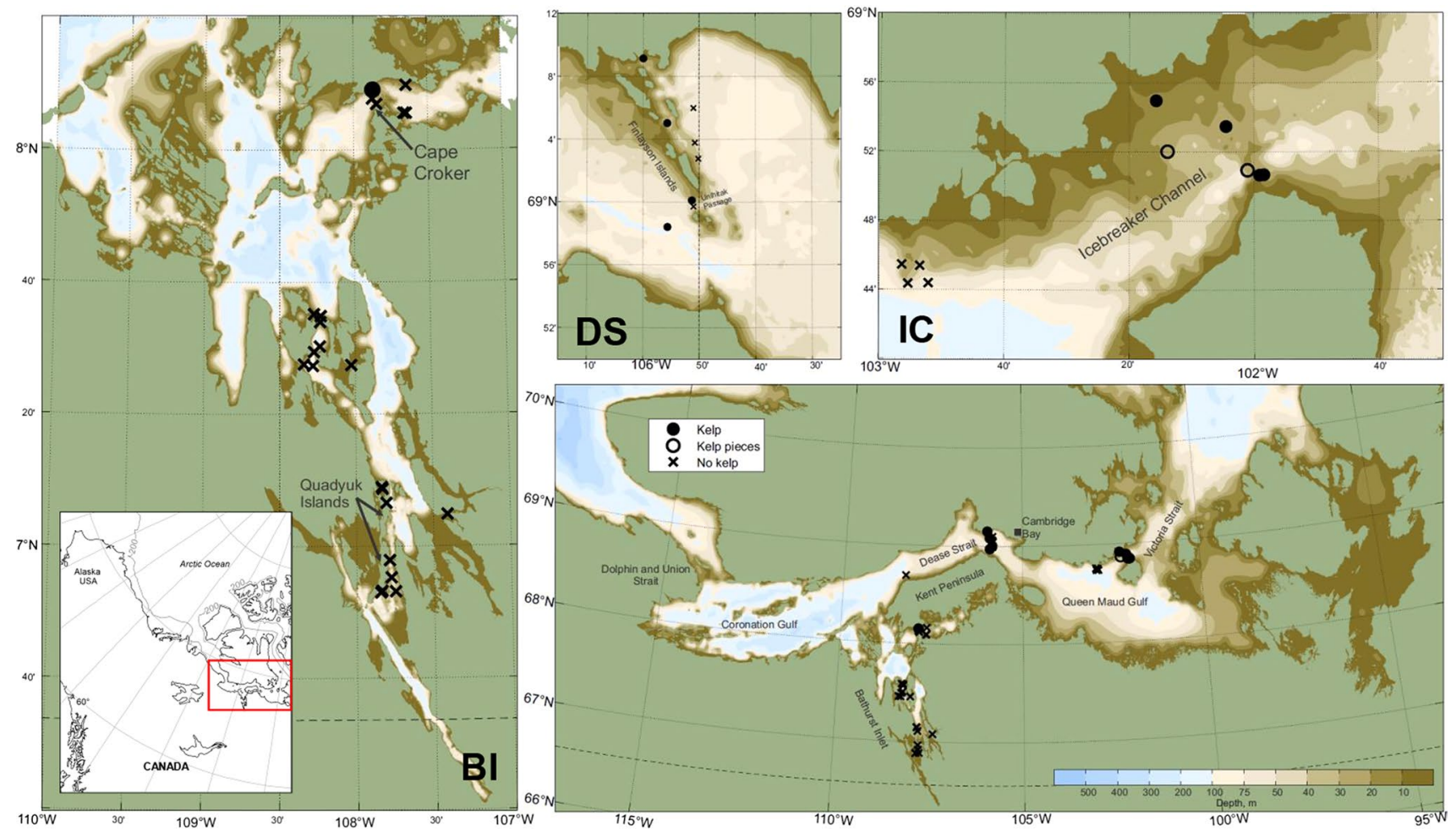
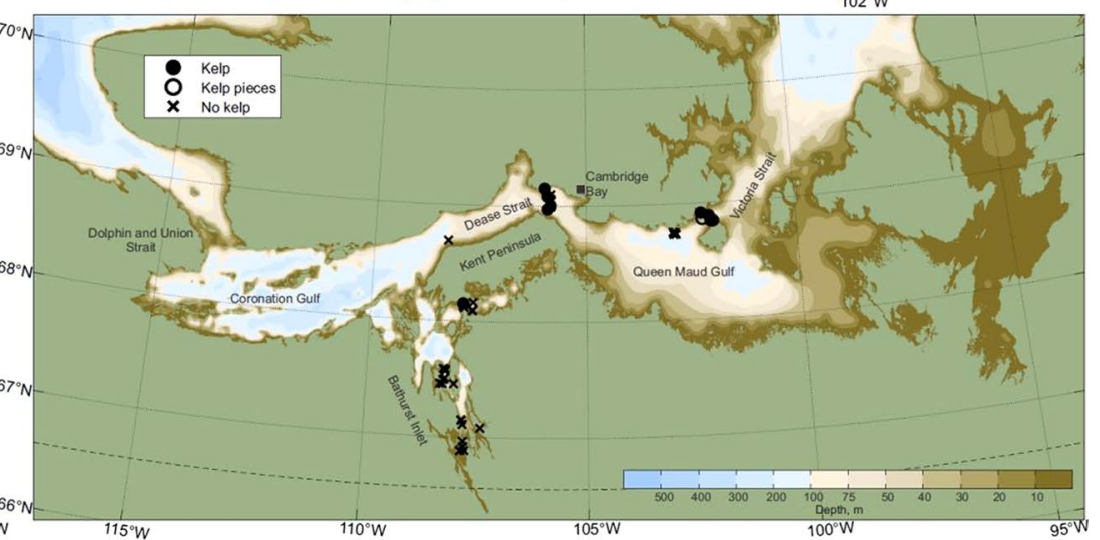

Fig. 1 Study region in the Northwest Passage with locations where we found attached kelp (black circles), unattached kelp pieces only (unfilled circles), and no kelp (crosses). IC Icebreaker Channel, DS
Dease Strait, BI Bathurst Inlet. The inset shows the location of the study area within Nord-America

current drift direction, had a target duration of $15 \mathrm{~min}$ at bottom while the vessel drifted with wind and currents at drift speeds between $\sim 0.2$ and $1.5 \mathrm{kn}$ (resulting in unequal areal coverage). At a drift of around $0.8 \mathrm{kn}$ the imagery became increasingly blurry, and very blurred images (in fast drift; see Table 1) as well as clearly overlapping images (in slow drift; see Table 1) were omitted from analysis. From 29 to 201 images per site were usable and were screened for kelp occurrence by viewing them in IrfanView software, and where needed enhancing contrast and applying the sharpening function. The percentage of images where kelp was detected was calculated per station and the kelp species present were noted for each location. The proportion of frames where unattached larger kelp pieces (detritus) could be detected as such was also recorded; small pieces would have gone undetected. Substrate was categorized as hard (boulder, gravel) or soft (sands, mud, silt). Fish were not visible in the imagery, and were likely scared away by the camera if present.

To obtain physical specimens that aided in identification of kelp and invertebrate taxa on the images, a small dredge was deployed at five sites each in Icebreaker Channel and Dease Strait; only one haul was possible in Bathurst Inlet (Cape Croker). The opening of the dredge was $55 \mathrm{~cm}$ wide and $25 \mathrm{~cm}$ high, and the attached bag $80 \mathrm{~cm}$ long with a (ca. $1000 \mathrm{~lm}$ ). Camera and ROV transects, oriented along the 


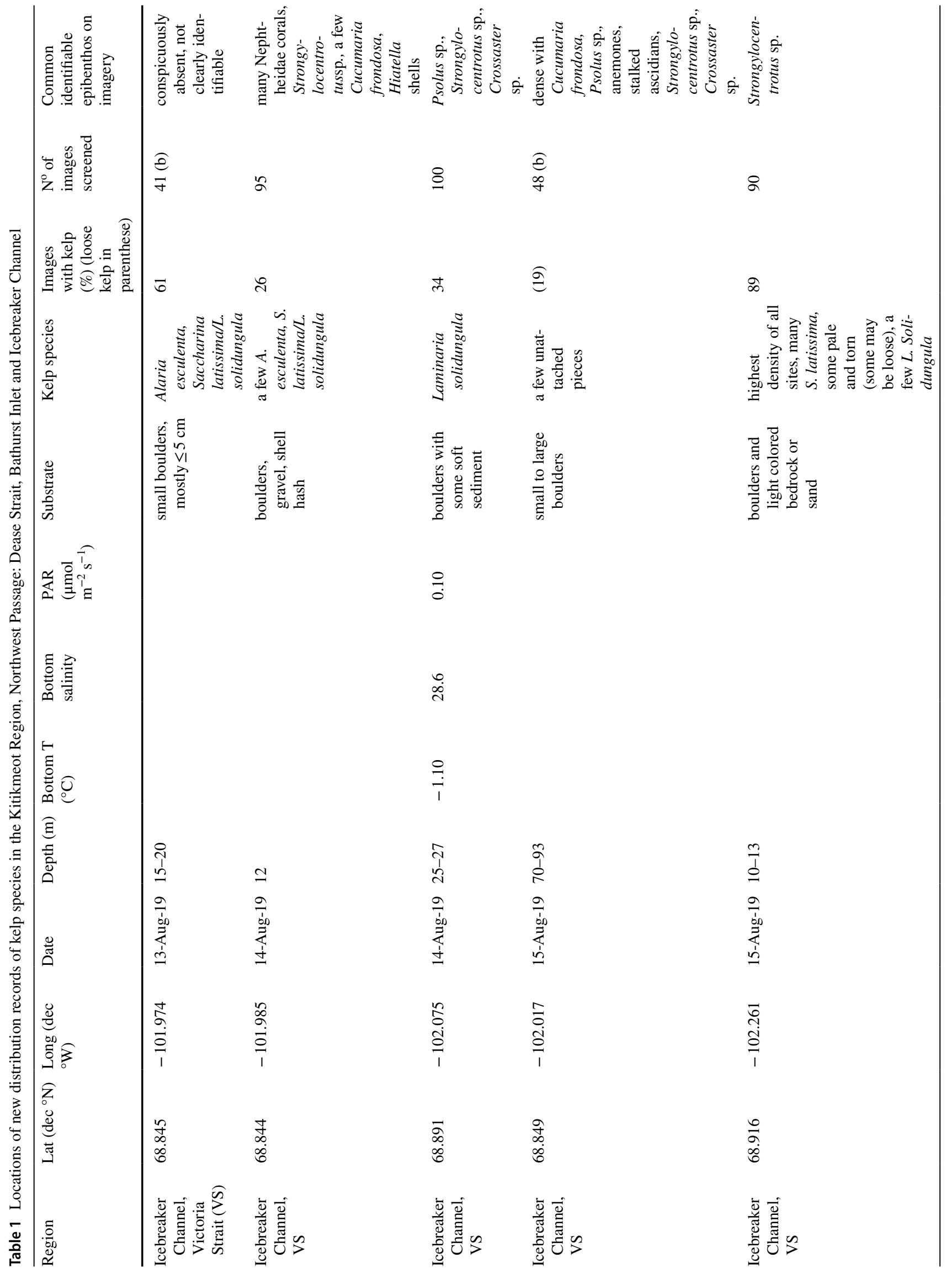


Polar Biology (2022) 45:719-736

723

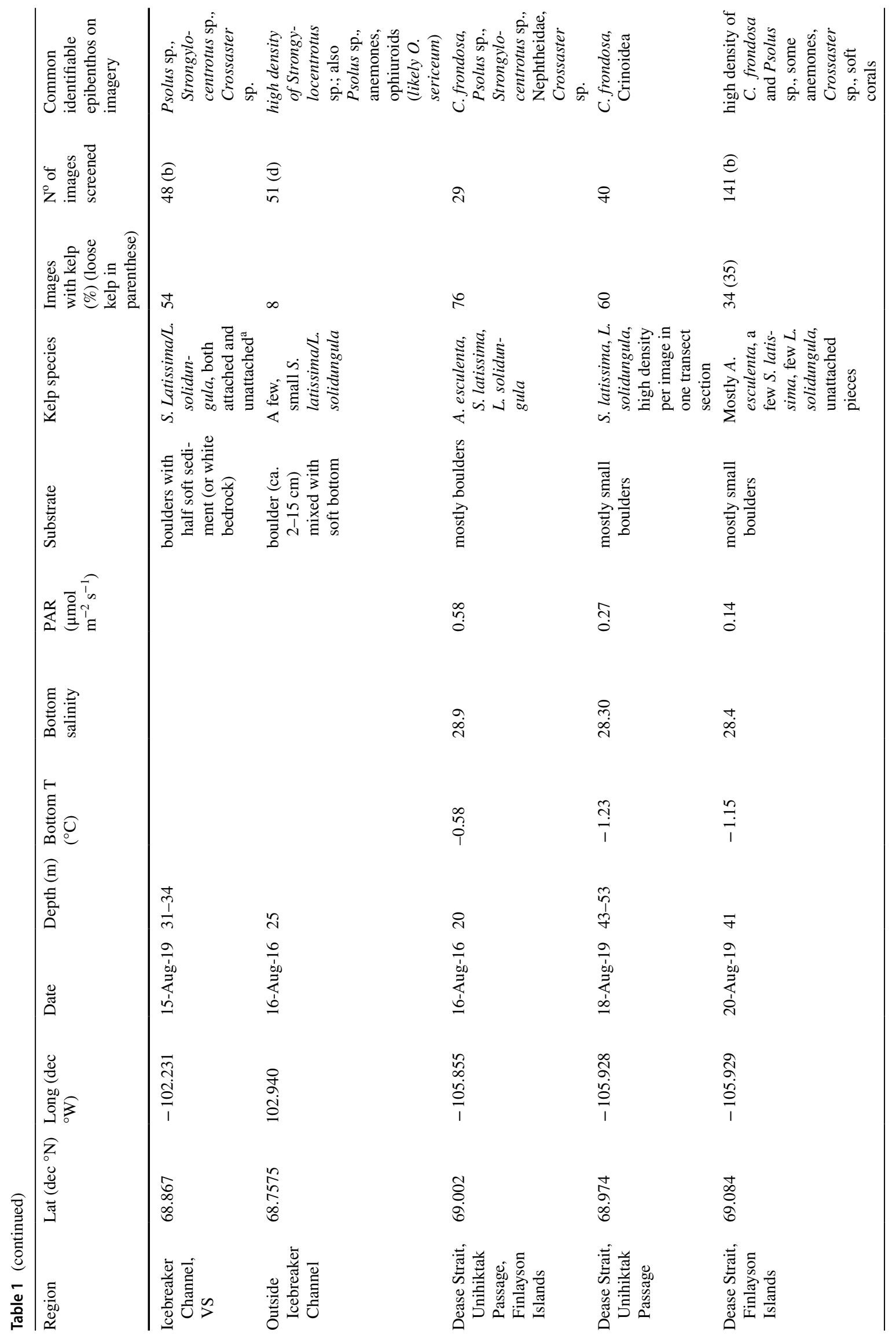

Springer 


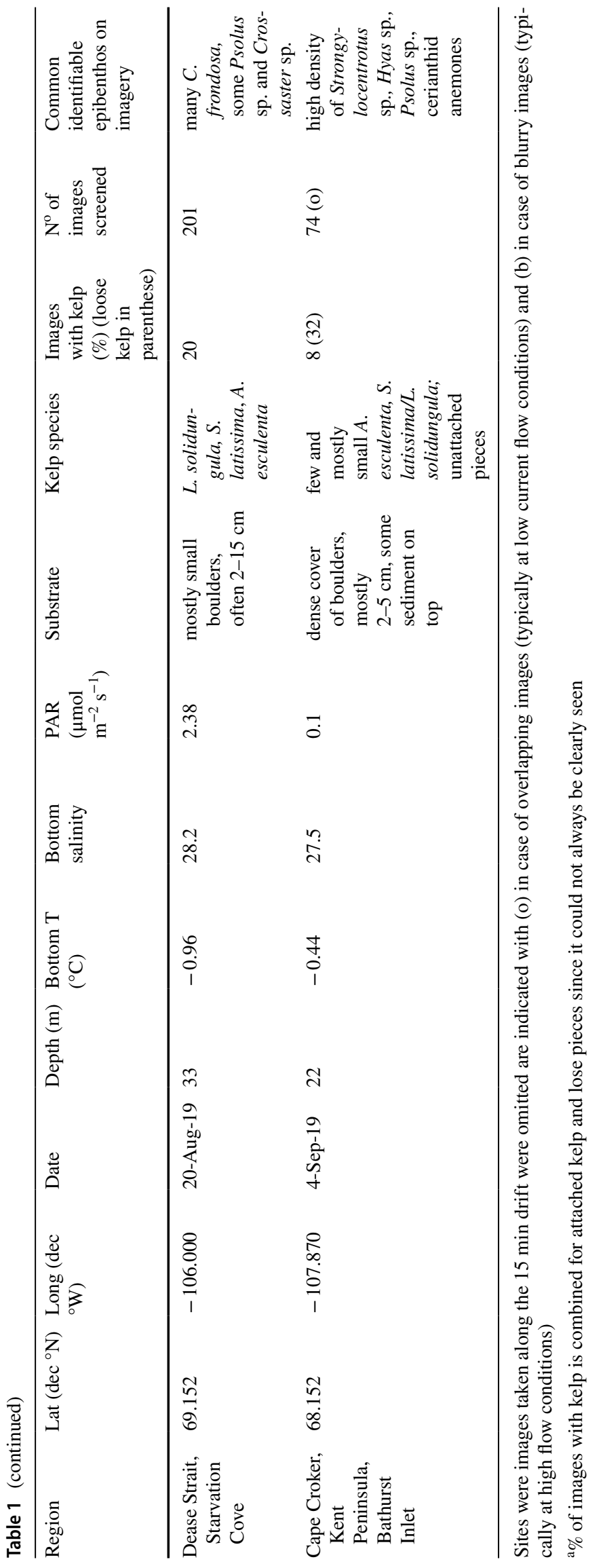


mesh of $1 \mathrm{~cm}$; ca. $30 \mathrm{~kg}$ additional weight was added to aid bottom contact in high flow regimes. The dredge was towed for 5-15 min at the bottom at 0.5-1 kn vessel speed (distances ca. 75-500 m) at depths from 20 to $90 \mathrm{~m}$. Kelp and invertebrates (the latter constituted the vast majority of the catch) collected were sorted and identified to the lowest practical taxonomic level. Taxonomic names were standardized to AlgaeBase (macroalgae) and the World Register of Marine Species (invertebrates). At camera-locations where kelp was detected, abundant detectable epifaunal invertebrates were also noted from the images for a given station.

\section{Characterization of oceanographic and habitat conditions}

During the field campaigns bottom temperature and bottom salinity were characterized at or in the vicinity of kelp sites with a Seabird SBE19+ conductivity-temperature-depth (CTD) rosette or an RBR Maestro CTD. To get a coarse approximation of the underwater light climate at kelp sites, PAR was measured with a LI-COR Li-193 spherical quantum sensor integrated into the Maestro or a LI-COR SN1018 sensor affixed to the SBE19+. Discrete samples for the determination of Nitrate + Nitrite (herein referred to as Nitrate) were collected in duplicate from rosette-mounted 6-L Niskin bottles, frozen immediately after collection and analyzed following the methods reported in McLaughlin et al. (2012). Samples were analyzed either at the Institute of Ocean Sciences (Sidney, BC) or aboard the CCGS Louis S. St. Laurent as part of the Joint Ocean Ice Study program on an Astoria nutrient auto-analyzer.

Typical current velocities at the kelp collection sites were estimated using output from a three-dimensional, unstratified, unstructured triangular grid mesh system tidal model. Water velocity is a relevant measure because it can enhance nutrient supply and thereby support seaweed growth (Hepburn et al. 2007). The model had variable horizontal resolution of down to $200 \mathrm{~m}$ in narrow straits, thereby even resolving passages through the Finlayson Islands, to as much as $10 \mathrm{~km}$ in wide gulfs (details in Rotermund et al. 2021). To characterize seasonal variability in temperature and salinity, data from an oceanographic mooring in Dease Strait (Unihiktak Passage) were used. The mooring was deployed annually from September 2016 to September 2019 and was equipped with three Seabird SBE37SM MicroCat CTD data loggers deployed at ca. $10 \mathrm{~m}, 20 \mathrm{~m}$ and $40 \mathrm{~m}$ depth. For Bathurst Inlet, the early spring/late winter hydrography was characterized using a CTD survey of Bathurst Inlet conducted in May 2009 via Twin Otter as part of the International Polar Year-Canada's Three Ocean's (IPY-C3O) project, while summer hydrography was determined during our 2019 field season aboard the RV Martin Bergmann, as described above.

\section{Results}

\section{Kelp taxa}

Three species of kelp were found across three areas of the study region and at multiple locations within each area (Table 1, Fig. 1). The species that were identified included Laminaria solidungula, Saccharina latissima, and Alaria esculenta (Fig. 2). Physical specimens of all three species were obtained from Unihiktak Passage in Dease Strait where taxonomic identification could be confirmed (Table 1, Fig. 2). All three species were found in both Victoria Strait in the area of Icebreaker Channel and in Dease Strait in the area of the Finlayson Islands to Unihiktak Passage. A. esculenta could be definitively identified from images at Cape Croker in Bathurst Inlet, though another kelp species was also present, $S$. latissima or $L$. solidungula. Other macroalgae species were also present on images but were not retrieved as physical specimens or systematically recorded. These included the genera Desmarestia and Fucus, a richly-branched, erect, filamentous red alga, a foliose red alga, and encrusting coralline algae.

At sites where kelp was present, proportions of images in which attached kelp was present varied from 8 to $89 \%$ (Table 1). Proportions were variable in all three regions; highest values were found at one of the shallowest sites, in Icebreaker Channel (10-12.5 m: Online Resource 1), and lowest at one of the sites at Cape Croker, compared to the other two regions. Unattached kelp pieces of unknown identity were seen in images from the seafloor in all three regions; where quantifiable, proportions were $32 \%$ and $35 \%$ (Table 1).

\section{Characterization of habitat conditions}

Kelp was observed over a wide range of depths (Fig. 3). For navigational safety reasons, vessel draft $(5 \mathrm{~m}) \mathrm{lim}-$ ited our observations to sites generally deeper than $10 \mathrm{~m}$. Sites with attached kelp ranged in depth from 10 to at least $43 \mathrm{~m}$, with most to $30 \mathrm{~m}$ or less (Table 1). Unattached drifting kelp pieces were seen (Online Resource 1e, f) near sites of attached kelp out to waters as deep as our maximum observation depth transect of 70-93 m in Icebreaker Channel, Victoria Strait.

At all locations where kelp was present at least some hard substrate was available. Based on visual assessment rock size ranged from gravel to smaller cobble and boulders (Fig. 2, Online Resource 1). Most sites in the matching depth range where kelp was absent (Fig. 1) were characterized as soft sediment, depositional bottoms with fine-grained sediments. Kelp was, however, also absent 
Fig. 2 Kelp species found in the Kitikmeot Sea, Northwest Passage. a Laminaria solidungula in Icebreaker Channel, b $L$. solidungula from Dease Strait on deck, c Saccharina latissima in Icebreaker Channel, $\mathbf{d} S$. latissima from Dease Strait on deck, e Alaria esculenta from Cape Croker, $\mathbf{f}$ A. esculenta from Dease Strait on deck
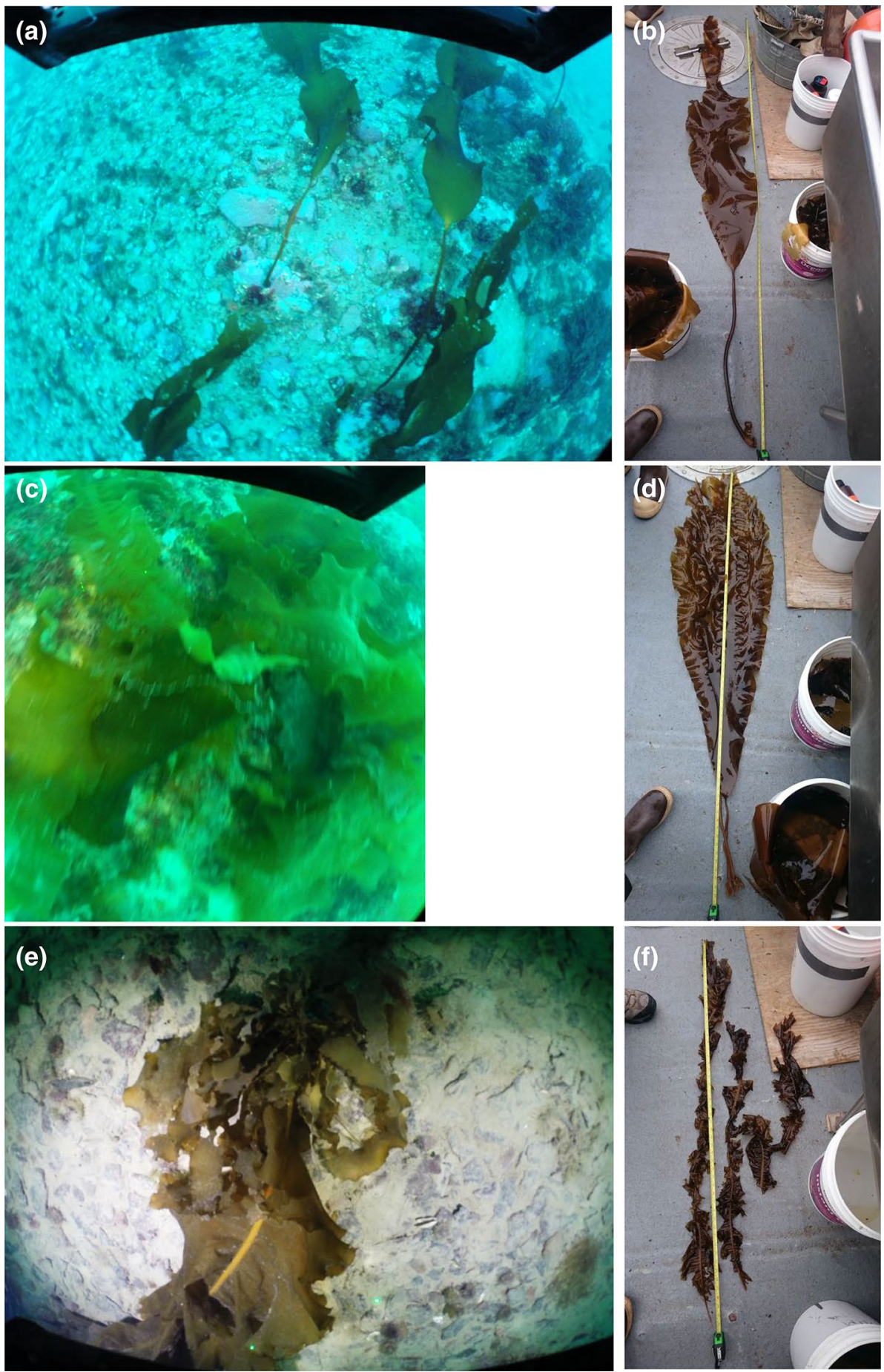

from a number of sites where interspersed hard substrate was available within the above depth ranges, specifically in narrow passages around Algak Island (sill depths around $10 \mathrm{~m}, 67.4904^{\circ} \mathrm{N}, 108.2730^{\circ} \mathrm{W}$ and $67.4555^{\circ}$ $\mathrm{N}, 108.2799^{\circ} \mathrm{W}$ ) and off North Quadyuk and Quadyuk islands $\left(66.9213^{\circ} \mathrm{N}, 107.7764^{\circ} \mathrm{W}\right.$ at $17 \mathrm{~m} ; 66.9647^{\circ} \mathrm{N}$, $107.7863^{\circ} \mathrm{W}$ at $27 \mathrm{~m}$ ), all in Bathurst Inlet (Fig. 1, Online Resource $1 \mathrm{~g}$ ).
A consistent pattern was shown in temperature and salinity profiles taken in August-September at sites where kelp was found: the upper $\sim 10 \mathrm{~m}$ were relatively warm and freshened by ice melt and river discharge; the pycnocline (resulting from both temperature and salinity gradients) was between roughly $10-20 \mathrm{~m}$; in some profiles a secondary step was evident near $40 \mathrm{~m}$, indicative of convective mixing the previous winter (Fig. 4). Bottom temperatures at kelp sites 
Fig. 3 Depth distribution of kelp recorded in the three study $D S$ Dease Strait, $B I$ Bathurst Inlet. Each circle represents one location which can include multiple images of which one or more contained kelp (filled circles) or unattached fragments (unfilled circles) regions. IC Icebreaker Channel,

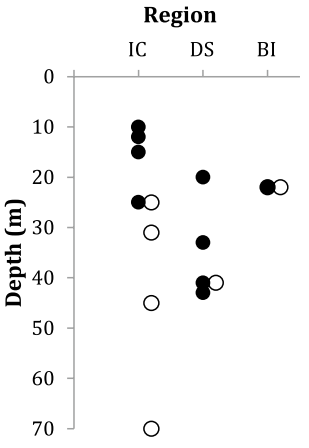

(a) teristics at and near sites where kelp was found during sampling days in Aug-Sept 2019. Temperature, salinity, irradiance and nutrients a Dease Strait, b Bathurst Inlet, c Icebreaker Channel. Colors represent different CTD casts at and near kelp sites with locations shown in Online Resource 3. Nutrient data are from discrete depths from Niskin bottles attached to the CTD. See Online Resource 2 for example profiles from regions where no kelp was found

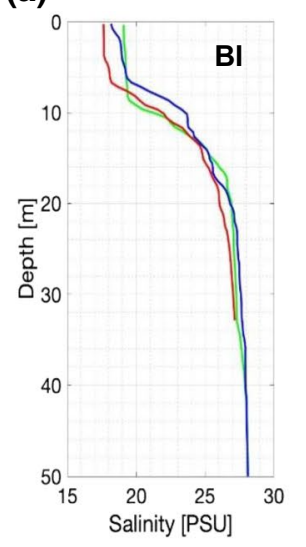

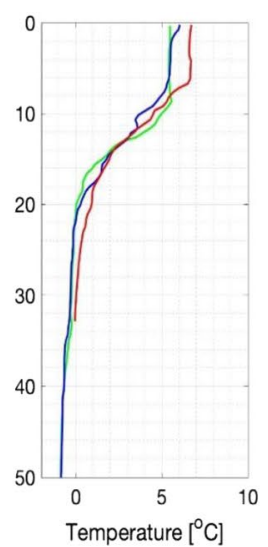
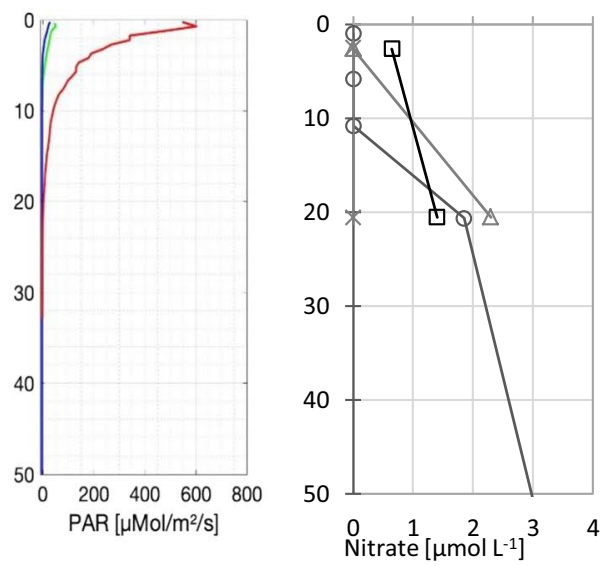

(b)
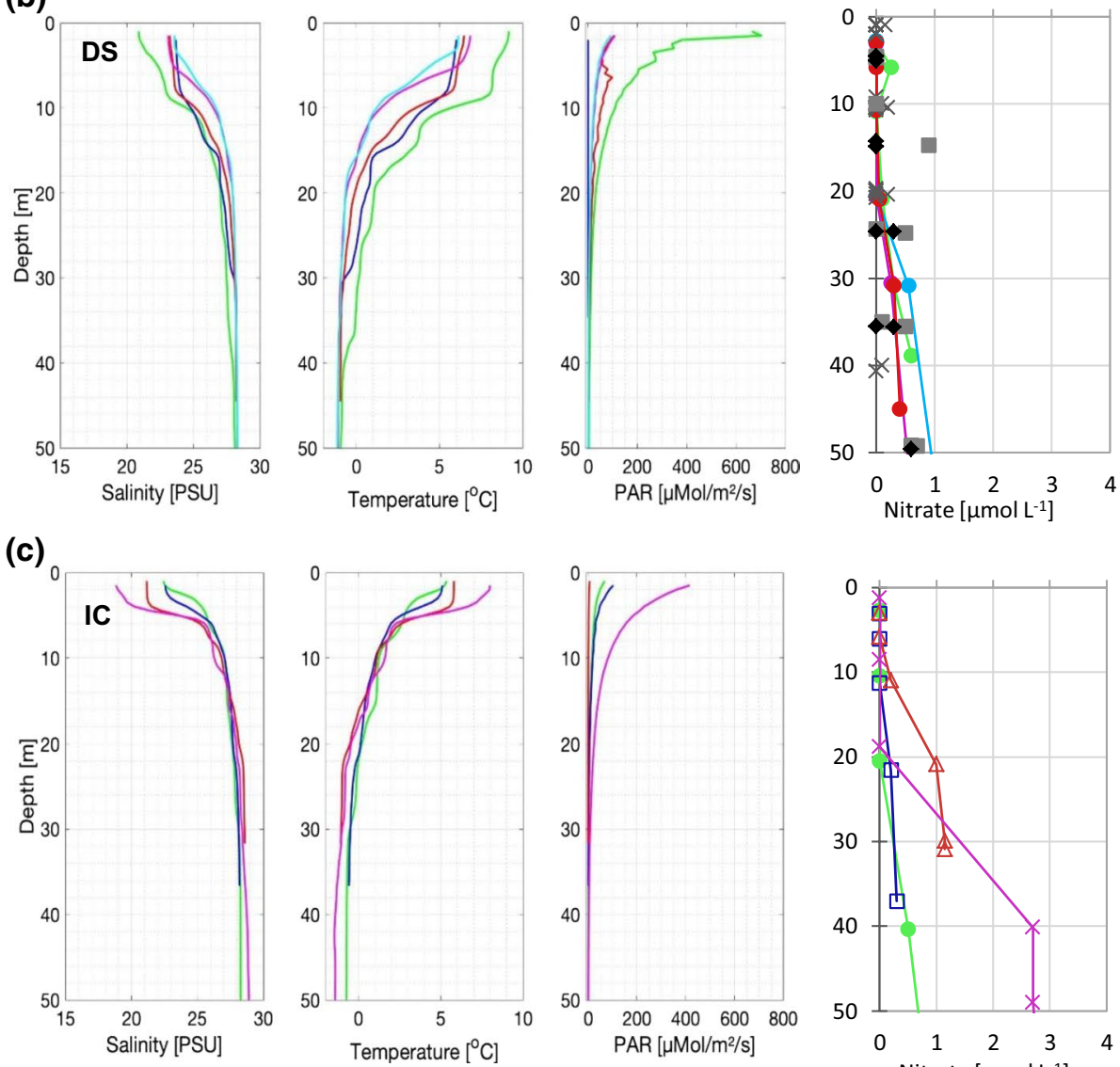

at $\sim 20 \mathrm{~m}$ and below in summer were in the sub-zero range to no higher than $1{ }^{\circ} \mathrm{C}$. Profiles taken near the shallower sites indicated that temperatures can reach $4-6{ }^{\circ} \mathrm{C}$ in the 10-14 m range where kelp was found (Fig. 4). Winter temperatures near the kelp sites in Dease Strait and Bathurst Inlet were in the subzero range in both surface and deeper layers (Fig. 5a, c). Bottom salinity was between 26 and 30 at kelp sites $\geq 20 \mathrm{~m}$ in summer, but dropped to as low as 20 in the 10-14 m range where our shallowest kelp sightings were (Figs. 3, 4). Winter salinity was between 26 and 28 throughout the water column near kelp sites (Fig. 5b, d). At sites 
(a)

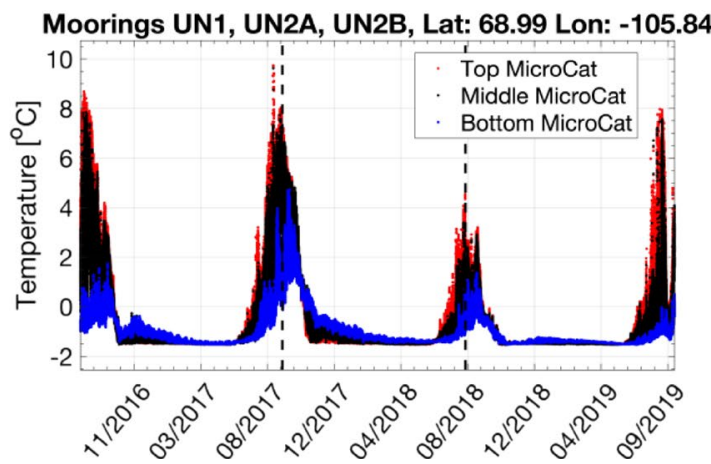

(c)

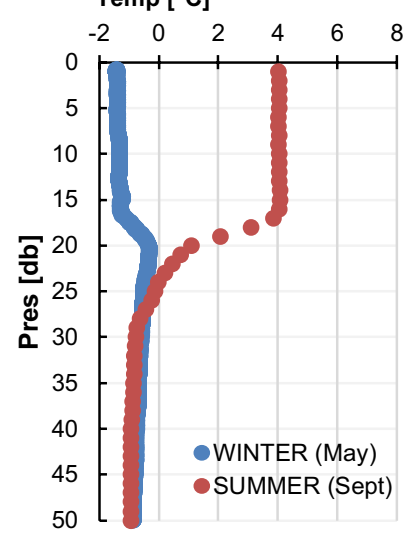

Fig. 5 Seasonal variation in temperature $(\mathbf{a}, \mathbf{c})$ and salinity $(\mathbf{b}, \mathbf{d})$ at locations near kelp sites. a, b Dease Strait at Unihiktak Passage from three years of mooring deployments. CTD data loggers were deployed at $\sim 12 \mathrm{~m}$ (top), 18-22 m (middle), and 38-40 m (bottom);

where kelp was absent but substrate appeared suitable (near Algak and Quadyuk Islands, see previous paragraph) the fresher and warmer surface layer was thicker in August-September than at sites were kelp was found and extended to $\sim 15-20 \mathrm{~m}$, followed by a sharper pycnocline (Online Resource 2); here we had no winter profiles available.

Irradiance was highly variable seasonally, spatially, throughout the day and depending on weather, so our measurements do not give an adequate reflection of this variation. In each region, however, one surface to depth profile was taken around local noon in mid-August-early September when surface PAR was in the range of 400 (Icebreaker Channel) to 600 (other two regions) $\mu$ mol photons $\mathrm{m}^{-2} \mathrm{~s}^{-1}$ in the surface water (Fig. 4), while the other profiles showed lower irradiances during afternoon or evening hours. The $1 \%$ light depths for mid-day, indicative of the approximate euphotic zone limit, were at $\sim 20-35 \mathrm{~m}$, suggesting some kelps were near the lower limit of the euphotic zone during the study period. At and near Algak and Quadyuk Islands where no kelp was found, mid-day light profiles indicated extremely low light levels below $10 \mathrm{~m}$ depth (Online Resource 2). (b)

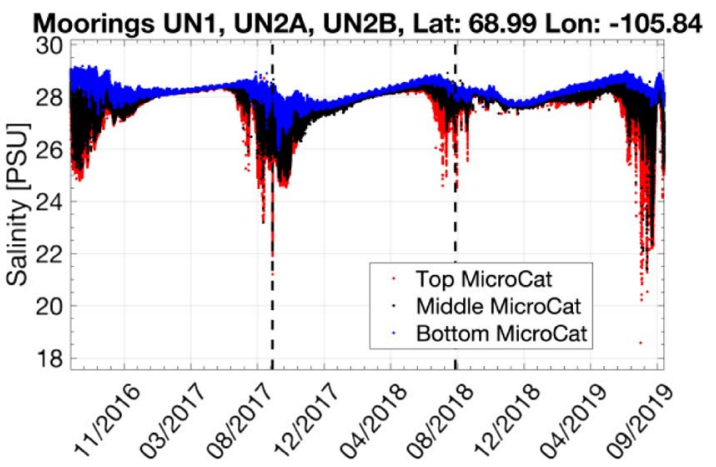

(d)

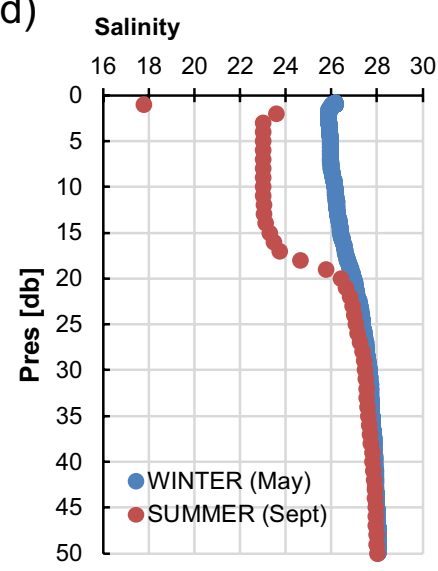

strong tidal currents and wind events led to an intermittent mooring drawdown of $\sim 5 \mathrm{~m}$; c, $\mathbf{d}$ CTD profiles near Cape Crooker in May and Sept of 2009. Note that kelp recorded below $\sim 20$ m experiences comparatively little seasonal variation

Water column profiles of nitrate (locations in Online Resource 3) showed depletion above the pycnocline in all three regions where kelp was found (Fig. 4). Nitrate reservoirs remaining below the pycnocline (where most of our kelps were recorded) increased with depth. While concentrations varied among sites they did not exceed $3 \mu \mathrm{mol} \mathrm{L} \mathrm{L}^{-1}$ at $50 \mathrm{~m}$ and remained below 2 and often below $1 \mu \mathrm{mol} \mathrm{L}{ }^{-1}$ at $20 \mathrm{~m}$. The sites where kelp was absent showed a similar pattern (Online Resource 2).

Maximum tidal current velocities over a 30-day period extracted for the kelp sites from the tidal model ranged from 20 to $70 \mathrm{~cm} \mathrm{~s}^{-1}$ (Fig. 6). Highest maximum velocities were found at the kelp sites off Jenny Lind Island in Icebreaker Channel (Victoria Strait region) and in Unihiktak Passage (Dease Strait region) (Fig. 6, Online Resource 4).

Invertebrate species that regularly co-occurred at kelp sites included suspension-feeding epifaunal taxa that also benefit from water motion such as nephtyid soft corals such as Gersemia sp., dendrochirotid sea cucumbers, Hiatella clams, and various anthozoan anemones (Table 1). In addition, potential kelp-grazers including limpets, trochid snails 

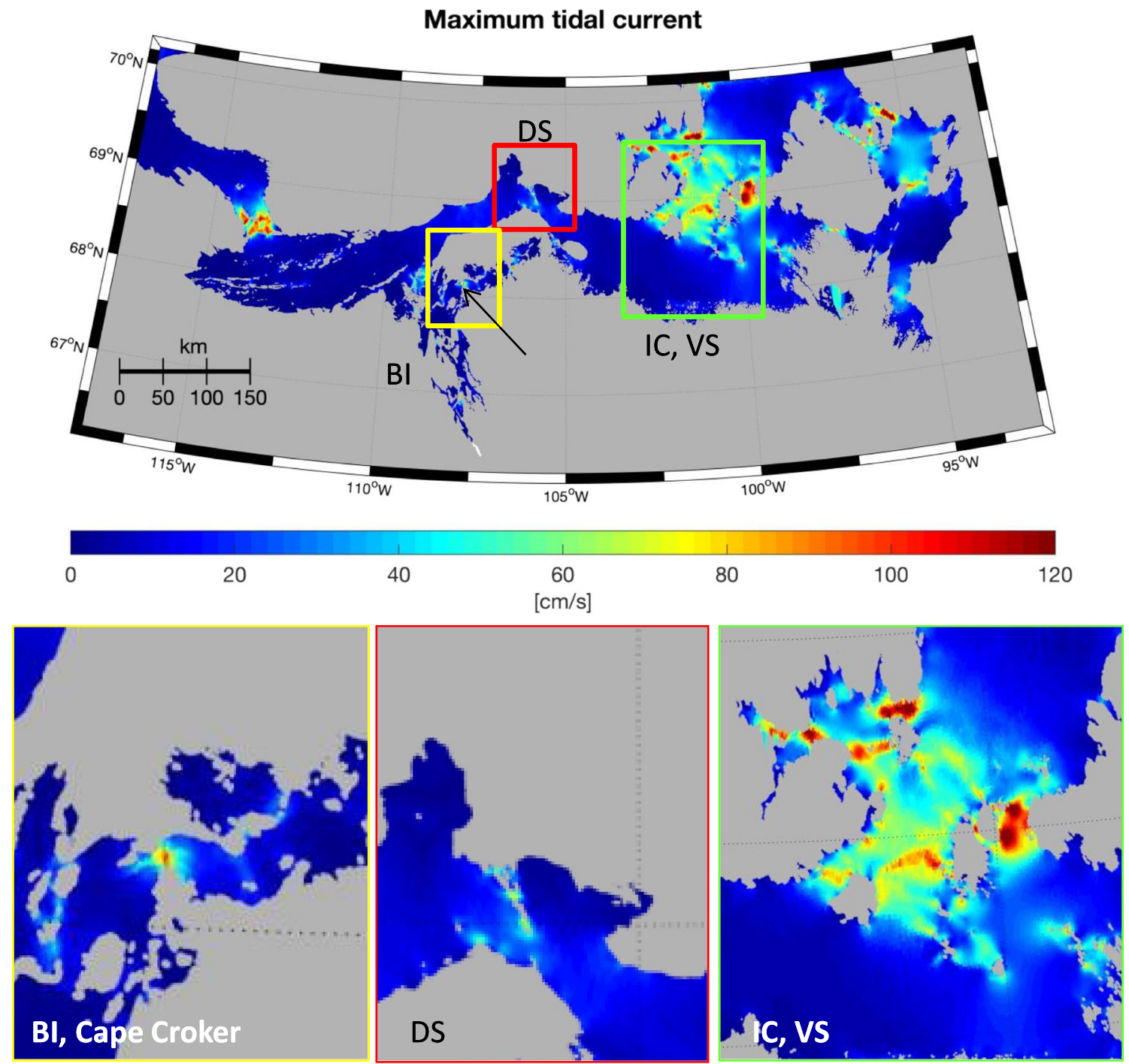

Fig. 6 Map of the maximum tidal current speed $[\mathrm{cm} / \mathrm{s}]$ over a 30-day period in the Kitikmeot Region showing peaks in areas where kelp was observed. Insets show the three regions where kelp observations were made: $B I$ Bathurst Inlet, DS Dease Strait, $I C$ Icebreaker Channel/VC Victoria Strait

pan-Arctic compilation by Filbee-Dexter et al. (2019). Kelp has, however, long been known to occur in the general study area by residents of local communities, yet this local knowledge was only recently documented in a coastal resource inventory (Nunavut Coastal Resource Inventory Cambridge Bay 2015; Table 2). This inventory mentions 'edible kelp' and 'hollow-stemmed kelp' (probably A. esculenta and S. latissima, respectively, R. Wilce Univ. Massachusetts Amhurst, pers. com.) for coastal stretches between Cambridge Bay, the Finlayson Islands and the northern side of the Kent Peninsula. Another recent coastal inventory, based on SCUBA transects along the $10 \mathrm{~m}$ isobath, also mentions the presence-yet very low abundance-of S. latissima in the areas of Cambridge Bay and the Finlayson Islands (Schulz et al. 2018; Table 2). In addition, the
The kelp distribution records presented here for Laminaria solidungula, Saccharina latissima and Alaria esculenta in the Kitikmeot Region are a new addition to the recent 
Table 2 Summary of available observations of kelp occurrence in the Kitikmeot Region study area

\begin{tabular}{|c|c|c|c|}
\hline Location & Species & Depth & References \\
\hline $\begin{array}{l}\text { Between Cambridge Bay and Finlayson } \\
\text { Islands, to northern coast of Kent } \\
\text { Peninsula }\end{array}$ & $\begin{array}{l}\text { Edible kelp (likely Alaria esculenta), } \\
\text { hollow-stemmed kelp (likely Saccha- } \\
\text { rina latissima) }\end{array}$ & $\begin{array}{l}\text { Not specified, but } \\
\text { likely shallow and } \\
\text { nearshore }\end{array}$ & $\begin{array}{l}\text { Nunavut Coastal Resources } \\
\text { Inventory Cambridge Bay } \\
(2015)\end{array}$ \\
\hline Cambridge Bay, Finlayson Islands & S. latissima & $10 \mathrm{~m}$ & Schultz et al. (2018) \\
\hline Unihitak Passage & Unspecified kelp & $19 \mathrm{~m}$ & CHS Natutical Chart 7750 \\
\hline Eastern Queen Maud Gulf & Laminaria sp., perhaps S. latissima & $24 \mathrm{~m}$ and $12 \mathrm{~m}$ & $\begin{array}{l}\text { Parks Canada } 2019 \text { video of } \\
\text { HMS Terror and HMS Erebus }\end{array}$ \\
\hline $\begin{array}{l}\text { Simpson Strait, eastern Queen Maud } \\
\text { Gulf }\end{array}$ & S. latissima & $21 \mathrm{~m}$ & Brown, DFO, pers. obs. in 2017 \\
\hline O'Reilly Island, SE Queen Maud Gulf & Unspecified kelp & n.d & $\begin{array}{l}\text { Carmarck, DFO, pers. obs., } \\
\text { in } 2014\end{array}$ \\
\hline Icebreaker Channel, Victoria Strait & $\begin{array}{l}\text { A. esculenta, S. latissima, Laminaria } \\
\text { solidungula }\end{array}$ & $20-27 \mathrm{~m}$ & This study \\
\hline $\begin{array}{l}\text { Dease Strait at Finlayson Islands and } \\
\text { Unihitak Passage }\end{array}$ & A. esculenta, S. latissima, L. solidungula & $20-43 \mathrm{~m}$ & This study \\
\hline $\begin{array}{l}\text { Cape Croker, Kent Peninsula in Bathurst } \\
\text { Inlet }\end{array}$ & A. esculenta, likely S. latissima & $22 \mathrm{~m}$ & This study \\
\hline
\end{tabular}

navigation chart used during our field campaigns (CHS Nautical Chart 7750: Approaches to Cambridge Bay) had kelp noted in the center of Unihitak Passage in Dease Strait, which inspired our sampling at that location where we confirmed the current occurrence of kelp. Finally, we point out that kelp (probably Laminiaria sp. and perhaps S. latissima) grows on the recently discovered vessels, HMS Terror (at $24 \mathrm{~m}$ depth) and HMS Erebus (12 m) of Sir John Franklin's Northwest Passage expedition, in the eastern part of Queen Maud Gulf (Parks Canada 2019, https://www.youtube. com/watch? v=OxyTZ3F7mkA). In nearby Simpson Strait $\left(68.5409^{\circ} \mathrm{N},-97.4596^{\circ} \mathrm{W}\right) \mathrm{KB}$ also found a viable-looking piece of $S$. latissima in a grab sample at $21 \mathrm{~m}$, and EC saw kelp in situ below the RV Bergmann in SE Queen Maud Gulf near O'Reilly Island in 2014 (Table 2).

The three kelp species noted here are typical features of Arctic rocky coasts of the Canadian Arctic Archipelago, Greenland, northern Norway, and various island groups such as Svalbard, Franz Josef Land and Novaja Semlja (Wilce 1994; Wiencke and Amsler 2012; Gavrilo et al. 2020; Johnson et al. 2020; Krause-Jensen et al. 2020). Laminaria solidungula, the only Arctic endemic kelp, has a broad distribution range across the Arctic and into temperate areas (Lüning 1990). Alaria esculenta and S. latisssima are common around the temperate North Atlantic (Araujo et al. 2016; Wilson et al. 2019) and extend northward to Svalbard and Greenland (at least $78^{\circ} \mathrm{N}$; Krause-Jensen et al. 2012; Bartsch et al. 2016). Bringloe et al. (2020), however, found that a separate Arctic lineage may in fact exist for at least A. esculenta rather than the Arctic records being a 'tolerant temperate outpost'. The closest reported occurrences to the west of our sites are, to our knowledge, in the so-called
Boulder Patch in Stefansson Sound, an assemblage of glacial drop stones in the otherwise soft permafrost-bordered coast of the central Beaufort Sea (Dunton and Jodwalis 1988; Wilce and Dunton 2014) and slightly further east of that in Camden Bay (Dunton et al. 1984). To the north, kelp was recorded from the coast of Devon and Somerset Islands, and to the east from (northern) Baffin Island (Cross et al. 1987; Küpper et al. 2016; Wilce 2016; Filbee-Dexter et al. 2019). While dispersal range is generally thought to be comparatively low for large brown seaweeds, genetic similarity patterns in an Alaria species suggested long-range dispersal, supported by regional and swift currents, does occur (Kusumo and Druehl 2000), and rafting blades can also produce viable spores. It seems, however, more likely that the observed and perhaps other kelp species also occur along the long, poorly-surveyed coast between the referenced sites and our observation sites, given rocky substrate is widely distributed throughout the Canadian Arctic Archipelago, and ice conditions do not massively differ along the southern parts of the Archipelago (Sou and Flato 2009). Other kelp species one might expect to find could, for example, include Agarum clathratum and S. longicruris, both found on Baffin Island (Küpper et al. 2016) and in West Greenland (Krause-Jensen et al. 2012).

\section{Habitat characteristics and requirements}

Most kelp occurrences reported here were between 10 and $30 \mathrm{~m}$. We could not determine the upper depth distribution limit of these kelps in the study area which tends to be determined by ice scouring at Arctic shores experiencing regular and long ice cover (Johnsen et al. 2020). In other areas, 
and likely within the study area, kelp occurs shallower than we were able to sample, e.g. A. esculenta and S. latissima peaked at $2.5 \mathrm{~m}$ in Kongsfjorden, Svalbard, an area however that rarely experiences sea ice cover today (Bartsch et al. 2016; Johnson et al. 2020). Ice scouring in the areas of the Finlayson Islands and Kent Peninsula is expected to extend no farther down than 2-3 m given the tidal range being typically below $1 \mathrm{~m}$ (Rotermund et al. 2021, tide-forecast.com), average ice type being first-year ice (Dalman et al. 2019; Derksen et al. 2019) and the lack of a reported stamukhi zone or substantial ridging. Icebreaker Channel, however, is known for ridging by sea ice including multi-year ice (Derksen et al. 2019), a fact early polar explorers seeking to find the Northwest Passage learned the hard way. Such ridging may affect the upper kelp limit in Icebreaker Channel. Based on observations from NW Baffin Island where the tidal range was $2.5 \mathrm{~m}$ at a maximum, sea ice tends to occur for a longer period than in our study area and perennial algae were absent from the upper $3 \mathrm{~m}$ under the low tide level (Küpper et al. 2016), we assume the upper limit for kelp in the Kitikmeot Region may be around 2-4 m (Fig. 7).

The lower distribution limit is driven by light limitation with the three species reported as rare below $\sim 15 \mathrm{~m}$ at some Arctic locations (Bartsch et al. 2016), yet may reach $30 \mathrm{~m}$ or more in clear water at other Arctic locations (Johnson et al. 2020, this study). Rare finds of kelps (Agarum clathratum and Saccharina spp.) to over $60 \mathrm{~m}$ were reported from Disco Bay (Boertmann et al. 2013). We found attached and viablelooking kelp to ca. $40 \mathrm{~m}$. Our observed maximum depth extent approximately matches the vertical extension of the euphotic zone (when defined as $1 \%$ surface irradiance in clear ocean water; Johnsen et al. 2020). Of the three species,
A. esculenta occurred deepest in Svalbard (Johnsen et al. 2020), but no difference in depth distribution was apparent among species in the present study; perhaps we had too few observations. Our deepest records around $40 \mathrm{~m}$ were in Dease Strait away from coastal run-off and where swift currents presumably keep visibility high and substrate coarse (and hence resuspension low) (Fig. 7).

In addition, several kelp sites were in passages of high tidal current flow and tidal mixing (Hannah et al. 2009; Rotermund et al. 2021). We propose that these sites may be particularly suited as kelp habitat for several reasons: Tidal currents maintain patches of open water in winter and spring (Williams et al. 2018), thereby resulting in a higher overall annual light amount than kelp specimens outside these tidal polynyas would experience. Also, the water movement may act to replenish nutrients through the regular flux, shear leading to vertical mixing and/or thinning the boundary layer between kelp and water (Fig. 7). Coastal run-off transporting low salinity water and enhancing turbidity may be the reason for absence of kelp at otherwise seemingly suitable sites such as around Algak Island in Bathurst Inlet as the thicker fresher layer and decreased light penetration at those sites suggest. Indeed, sedimentation effects have been documented to limit growth in the Boulder Patch in the Beaufort Sea, a coast with high erosion rates and nearby river run-off (Bonsell and Dunton 2018).

The temperature range we measured is at the lower end of the known thermal ranges for S. latissima and A. esculenta. It is within the thermal range for L. solidungula, though generally below the proposed optimal growth temperatures. The optimal growth temperature for S. latissima is reported as around $10^{\circ} \mathrm{C}$ (Fortes and Lüning 1980) and

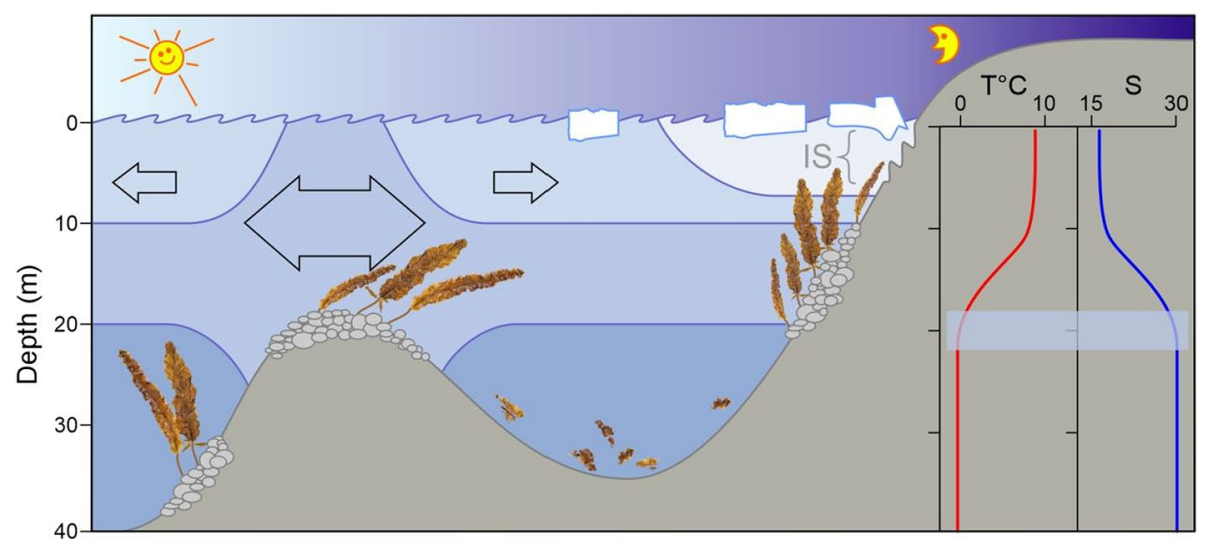

Fig. 7 Conceptual schematic showing kelp distribution and habitat conditions encountered in the study area. The (proposed) roles of high current flows in passages and of ice scour (IS) in shore areas are shown. Specifically, environmental conditions are more favorable underneath the warm (in summer) and very cold (in winter) and fresh surface layer (light blue) and ice-scoured coastal zone (whitish) that limits light penetration and though mechanical disturbance pushes depth distribution deeper. Tidal currents (thick arrow) are thought to enhance nutrient supply (in the mid-blue shaded layer) through mixing and regular advective flow and-indirectly through reducing sea ice cover and/or duration-total light amount. Off-shore, little turbidity may allow kelp to occur deep in stable and fully marine, nutrient rich conditions. Kelp detritus may reach deeper areas away from sites where kelp grows 
that of zoospores of S. latissima and A. esculenta for photosynthesis at $7-13{ }^{\circ} \mathrm{C}$ (Svalbard, Roleda 2009). In a latitudinal test-farming experiment some of the best growth rates for S. latissima sporophytes were, however, observed at temperatures below $10{ }^{\circ} \mathrm{C}$ at $69^{\circ} \mathrm{N}$ in northern Norway (Forbord et al. 2020), a latitude comparable to this study yet with generally warmer temperatures than in our study area. The temperature range for optimum growth of $L$. solidungula sporophytes was somewhat lower, at $5-10{ }^{\circ} \mathrm{C}$ (Wiencke and Amsler 2012 and references therein). In terms of salinity tolerance windows, quantum yield of the photosynthetic system was high (upwards of $80 \%$ compared to a control) at salinities between 10-50, 20-50 and 25-55 for A. esculenta, L. solidungula and S. latissima, respectively, in an experimental set-up in Svalbard (Karsten 2007). A more recent multi-stressor experiment showed that the combined treatment of increased temperature and reduced salinity (25), resulted in decreased maximum quantum yield in L. solidungula (the other two species were not studied; Diehl et al. 2020). Based on these findings, the specimens we found-mostly below the pycnocline-were likely not salinity stressed at these sites, but the upper occurrence limit of kelp in the study area may be influenced by low salinity (and potentially combined temperature) stress. Perhaps the absence of kelp from two sites that were shallow enough and had hard substrate could be related to the thicker freshwater-influenced layer and low light levels there. Exposure to low salinity may not only reduce photosynthetic activity and growth (Diehl et al. 2020; Forbord et al. 2020) and the ability of gametophytes to produce sporophytes (Muth et al. 2021) but eventually also result in bleaching or mortality (Karsten 2007).

The invertebrate community associated with kelp occurrence is likely explained by a combination of shared habitat preferences, trophic interactions and shelter. Several of the taxa co-occurring with the observed kelps also require hard substrate for attachment and sufficient water flow for suspension feeding. For example, suspension-feeding sea cucumbers such as Cucumaria frondosa and Psolus spp., soft corals such as of the genus Gersemia, Hiatella clams and Crinoidea (feather stars) were dominant in high-flow tidal passages in the study area where kelp occurred (when sites were shallow enough) (Online Resource 5), while depositfeeding brittle stars and polychaetes dominated soft bottom and low-flow sites (Fredriksen 2018). Grazing taxa such as sea urchins Strongylocentrotus sp., snails including Margarites spp., and limpets, Lepeta caeca, previously found associated with kelps and other macroalgae in other Arctic locations, can feed on kelp (Lippert et al. 2001; Schuster and Konar 2014; Johnsen et al. 2020). The sea urchins were in fact among the most numerous taxon in dredge hauls at all three kelp sites and have elsewhere been shown to both reduce kelp biomass (Sivertsen 1997; Konar and Estes 2003) and enhance kelp detritus dispersal through transferring kelp into urchin feces (Wernberg and Filbee-Dexter 2018). Yet other taxa occurring in kelp systems are known to benefit from the protective environment of these systems including their holdfasts (Orland et al. 2016).

At deeper locations where drifting pieces of kelp were observed in our study, they add to the detrital food web after degradation, as has been documented for areas in the vicinity of macroalgal coasts and fjords around the Arctic (Dunton and Schell 1987; Renaud et al. 2015; Pedersen et al. 2020). The Kitikmeot Region is an oligotrophic system (Ardyna et al. 2011; Crawford et al. 2018; Brown and Williams, Dept. Fisheries \& Oceans Canada, unpubl. data) though recent data suggest the region may be more productive than previously thought (Dezutter et al. 2021). In either case macroalgal carbon in addition to other potential sources such as terrestrial carbon and microphytobenthos in shallow waters may provide relevant contributions for the consumers in the ecosystem.

\section{Considerations on future kelp occurrence in the Kitikmeot Region}

Given local knowledge confirms the historical presence of kelp in the study area it seems unlikely that our observations of kelp occurrence per se are related to recent ecosystem changes. At other Arctic locations, however, abundance and composition of macroalgae are currently undergoing change (Keck Al-Hababeh et al. 2020; Krause-Jensen et al. 2020). Where observational time series could be compiled, in many-yet not all-areas biomass had increased over the past decades, some boreal species had expanded their ranges northward, and/or biomass had shifted to shallower depths (Kortsch et al. 2015; Bartsch et al. 2016; KrauseJensen et al. 2020). Modeling approaches predicted northward extensions of kelp distributions (including Saccharina latissima) to continue, along with a coincident contraction in the southern distribution range by 2100 under a high emissions scenario (RCP8.5; Wilson et al. 2019). These studies explained these trends as due to reduced ice cover and scour, and thereby increased light availability. While sea ice has declined more slowly in the Canadian Arctic Archipelago than in other parts of the Arctic, declines have still been observed (Derksen et al. 2019) and model runs projected this trend continue (Sou and Flato 2009) though recent changes in the seasonal, fast ice zone have been much smaller than those more commonly reported from a perennial, pack-ice perspective, where changes are much greater (Humfrey Melling, Inst. of Ocean Sciences, pers. comm.). For example, records from Cambridge Bay extending back over 60 years showed thinning rate of only $0.025 \mathrm{~m} /$ decade (Niemi et al. 2019). Yet, declines in extent and/or thickness will yield 
increasingly more open water days and/or higher light transmission through thinner ice.

As such, in situ temperatures in the summer surface mixed layer will increasingly overlap with the growth optima of the observed kelp species in the future, and summer temperatures in the upper subtidal may also exceed the optimum growth optimum of $L$. solidungula at times $\left(5-10{ }^{\circ} \mathrm{C}\right.$, tom Dieck 1992) in the future. Perhaps this species would, however, continue to fare well below the surface mixed layer. For the coming decades, temperature conditions and open water days combined with the availability of rocky substrates for attachment suggest expansion of kelp occurrence in the Kitikmeot Region is conceivable. The combination of advective and vertical nutrient flux will remain highest in the high flow passages studied, and combined with more open water days and absence of turbidity likely render these passages suitable and perhaps optimal habitats as long as they are not below the euphotic zone. While shallow subtidal shore areas have more preferable light levels, they suffer from seasonal nutrient limitation, higher turbidity and sub-optimal salinity. Increased turbidity from river estuaries throughout the Kitikmeot Region's coastline, tundra and wetlands primarily of the southern shores of the study area (CAVM team 2003) could counteract kelp biomass increases from ice decline in some nearshore regions as shown elsewhere (Bonsell and Dunton 2018) and suggested by models (Scherrer et al. 2019). In addition to the increasing number of ice-free days, we hypothesize that the interplay of bottom depth (limiting light) and strength of stratification (limiting nutrient availability) will play a role in setting future trends in kelp growth in the study area, and that horizontal through-flow and vertical nutrient flux in tidal passages may be the key to enhanced growth in such locations (conceptually depicted in Fig. 7).

Systematic transects perpendicular to shore, perhaps as part of community-based monitoring efforts, would greatly expand knowledge of present (depth) distribution patterns and environmental envelopes of kelp in the Kitikmeot Region and could also feed into the characterization of coastscape types as set as a goal by the Conservation of Arctic Fauna and Flora (CAFF 2019). From this type of habitat mapping the potential for future expansion, and perhaps human consumption, could be inferred. We conclude that our study, while limited in regional coverage and taxonomic resolution, provides evidence (1) that the Kitikmeot Region generally contains habitat suitable for kelp occurrence and growth, and (2) that locations with strong tidal currents, located in particular in narrow passages between islands or island and mainland, may be locations particularly suited for kelp growth. We propose such locations are suitable because they contain a combination of hard substrate, limited turbidity from run-off from land, a longer open water period with, time-integrated, more light and tidal currents providing a mechanism that moves up nutrients through breaking the elsewhere strong pycnocline.

Supplementary Information The online version contains supplementary material available at https://doi.org/10.1007/s00300-022-03007-6.

Acknowledgements Logistical and science support onboard including image acquisition was provided by the Captains and crew of the R/V Martin Bergmann, the Arctic Research Foundation (with special thanks to A. Schimnowski), as well as by M. Dempsey and C. Clarke (Institute of Ocean Sciences), S. Marriott (Hamlet of Cambridge Bay), and R. Descoteaux (UiT The Arctic University of Norway) and N. AcharyaPatel (2019 Rolex scholar). Image work was supported by R. Fredriksen and A. Keck. We thank K. Dunton (Univ. of Texas at Austin) and R. Wilce (retired from Univ. Massachusett Amhurst) for helpful insights on Arctic kelp and discussion of species identification, and P Kimber for generating the digital version of Figure 7. We thank K. MacGregor and two anonymous reviewers for thorough reviews and constructive comments that helped improve an earlier version of the manuscript.

Authors contribution EC conceptualized the study idea. All authors participated in the field work. BB screened the images for kelp occurrence. WW, LR, KB, SD and EC acquired the physical-chemical oceanography data, and LR and KB quality controlled and visualized these. WW made the study area map. BB wrote the draft manuscript, and all co-authors commented on and approved it.

Funding Open Access funding was provided by UiT The Arctic University of Norway. Funding for the Kitikmeot Sea Science Study was provided by Polar Knowledge Canada (grant number NST-1617-0027) with special thanks to O. Schimnowski, by the Institute of Ocean Sciences and the Department of Fisheries and Oceans Arctic Science Fund (2019). BB's contribution was done as part of the Arctic Seasonal Ice Zone Ecology initiative co-funded by UiT - The Arctic University of Norway and the Troms $\varnothing$ Research Foundation (project number $01 \mathrm{vm} /$ h15). SD acknowledges support of the University of Alaska Fairbanks.

Data availability The physical-chemical oceanography data and images can be made available through contacting the authors. Code availability - not applicable.

\section{Declarations}

Conflict of interest The authors declare that they have no conflict of interest.

Ethical approval This publication is part of the Kitikmeot Sea Science Study which operates under a scientific research license issued by the Nunavut Research Institute (\#04 02817 N-M; 04019 18R-M; \#04 026 19R-M).

Consent to participate Not applicable.

Consent for publication Not applicable.

Open Access This article is licensed under a Creative Commons Attribution 4.0 International License, which permits use, sharing, adaptation, distribution and reproduction in any medium or format, as long as you give appropriate credit to the original author(s) and the source, provide a link to the Creative Commons licence, and indicate if changes were made. The images or other third party material in this article are included in the article's Creative Commons licence, unless indicated otherwise in a credit line to the material. If material is not included in 
the article's Creative Commons licence and your intended use is not permitted by statutory regulation or exceeds the permitted use, you will need to obtain permission directly from the copyright holder. To view a copy of this licence, visit http://creativecommons.org/licenses/by/4.0/.

\section{References}

Araújo RM, Assis J, Aguillar R, Airoldi L, Bárbara I, Bartsch I, Bekkby T, Christie H, Devoult D, Derrien-Courtel S, Fernandex C, Fredriksen S, Gevaert F, Gundersen H, Le Gal A, Levequew L, Mieszkowska N, Norderhaug KM, Oliveira P, Puente A, Rico JM, Rinde E, Schubert H, Strain EM, Valero M, Viard F, Sousa-Pinto I (2016) Status, trends and drivers of kelp forests in Europe: an expert assessment. Biodivers Conserv 25:1319-1348

Archambault P, Snelgrove PVR, Fisher JAD, Gagnon J-M, Garbary DJ, Harvey M, Kenchington EL, Lesage V, Levesque M, Lovejoy C, Mackas DL, McKindsey CW, Nelson JR, Pepin P, Piche L, Poulin M (2010) From sea to sea: Canada's three oceans of biodiversity. PLoS ONE 5(8):e12182. https://doi.org/10.1371/journ al.pone. 0012182

Ardyna M, Gosselin M, Michel C, Poulin M, Tremblay JÉ (2011) Environmental forcing of phytoplankton community structure and function in the Canadian High Arctic: contrasting oligotrophic and eutrophic regions. Mar Ecol Prog Ser 442:37-57

Bartsch I, Paar M, Fredriksen S, Schwanitz M, Daniel C, Hop H, Wiencke C (2016) Changes in kelp forest biomass and depth distribution in Kongsfjorden, Svalbard, between 1996-1998 and 20122014 reflect Arctic warming. Polar Biol 39:2021-2036. https:// doi.org/10.1007/s00300-015-1870-1

Bonsell C, Dunton KH (2018) Long-term patterns of benthic irradiance and kelp production in the central Beaufort Sea reveal implications of warming for Arctic inner shelves. Prog Oceanogr 162:160-170. https://doi.org/10.1016/j.pocean.2018.02.016

Boertmann D, Mosbech A, Schiedek D, Dünweber M (eds ) (2013) Disko West. A strategic environmental impact assessment of hydrocarbon activities. Scientific Report from Danish Centre for Environment and Energy No. 71, DCE-Danish Centre for Environment and Energy, Aarhus University

Brown KA, Williams WJ, Carmack EC, Fiske G, François R, McLennan D, Peucker-Ehrenbrink B (2020) Geochemistry of small Canadian Arctic Rivers with diverse geological and hydrological settings. J Geophys Res Biogeosciences 125(1): e2019JG005414

Bringloe TT, Verbruggen H, Saunders GW (2020) Unique biodiversity in Arctic marine forests is shaped by diverse recolonization pathways and far northern glacial refugia. Proc Nat'l Acad Sci 117(36):22590-22596

CAFF (2019) Arctic coastal biodiversity monitoring plan. Conservation of arctic flora and fauna international secretariat: Akureyri, Iceland

Carmack EC, Yamamoto-Kawai M, Haine TW, Bacon S, Bluhm BA, Lique C, Melling H, Polyakov I, Straneo F, Timmermans M-L, Williams WJ (2016) Freshwater and its role in the Arctic marine system: sources, disposition, storage, export, and physical and biogeochemical consequences in the Arctic and global oceans. J Geophys Res: Biogeosci 121:675-717

CAVM Team (2003) Circumpolar Arctic Vegetation Map. (1:7,500,000 scale), Conservation of Arctic Flora and Fauna (CAFF) Map No 1. US Fish and Wildlife Service, Anchorage, Alaska

Chung IK, Beardall J, Mehta S, Sahoo D, Stojkovic S (2011) Using marine macroalgae for carbon sequestration: a critical appraisal. J Appl Phycol 23:877-886

Costa M, Le Baron N, Tenhunen K, Nephin J, Willis P, Mortimor JP, Dudas S, Rubidge E (2020) Historical distribution of kelp forests on the coast of British Columbia: 1858-1956. Appl Geogr 120:102230

Crawford DW, Cefarelli AO, Wrohan IA, Wyatt SN, Varela DE (2018) Spatial patterns in abundance, taxonomic composition and carbon biomass of nano-and microphytoplankton in Subarctic and Arctic Seas. Progr Oceanogr 162:132-159

Cross WE, Wilce RT, Fabijan MF (1987) Effects of experimental releases of oil and dispersed oil on Arctic nearshore macrobenthos. III Macroalgae Arctic 40:211-219

CHS Nautical Chart 7750: Approaches to Cambridge Bay

Dalman LA, Else BG, Barber D, Carmack E, Williams WJ, Campbell K, Duke PJ, Kirillov S, Mundy CJ (2019) Enhanced bottom-ice algal biomass across a tidal strait in the Kitikmeot Sea of the Canadian Arctic. Elem Sci Anthr 7:22

Derksen C, Burgess D, Duguay C, Howell S, Mudryk L, Smith S, Thackeray C, Kirchmeier-Young M (2019) In: Bush E, LeChanges DS (eds) Snow, ice, and permafrost across Canada. Canada's changing climate report. Government of Canada, Ottawa, Ontario, Canada, pp 194-260

Dezutter T, Lalande C, Darnis G, Fortier L (2021) Seasonal and interannual variability of the Queen Maud Gulf ecosystem derived from sediment trap measurements. Limnol Oceanogr 66:S411-S426

Diehl N, Karsten U, Bischof K (2020) Impacts of combined temperature and salinity stress on the endemic Arctic brown seaweed Laminaria solidungula J Agardh. Polar Biol 43:647-656

Dumais PO (2020) Modelling benthic communities in the Kitikmeot area, Canadian Archipelago, Arctic MS thesis, Laval University

Dunton KH, Jodwalis CM (1988) Photosynthetic performance of Laminaria solidungula measured in situ in the Alaskan High Arctic. Mar Biol 98:277-285. https://doi.org/10.1007/BF00391206

Dunton KH, Schonberg SV, Schell DM (1984) Biological reconnaissance of Boulder Island Shoal in Western Camden Bay, Beaufort Sea, Alaska. US Department of Commerce, National Oceanic and Atmospheric Administration, National Ocean Service, Office of Oceanography and Marine Assessment, Alaska Office

Dunton KH, Schell DM (1987) Dependence of consumers on macroalgal (Laminaria solidungula) carbon in an arctic kelp community: ${ }^{13} \mathrm{C}$ evidence. Mar Biol 93:615-625

Filbee-Dexter K, Wernberg T, Fredriksen S, Norderhaug KM, Pedersen MF (2019) Arctic kelp forests: diversity, resilience and future. Glob Planet Change 172:1-14

Forbord S, Matsson S, Brodahl GE, Broch OJ, Bluhm BA, Christie H, Handå A, Metaxas A, Steinhovden KB, Skjermo J, Olsen Y (2020) Latitudinal, seasonal and depth dependent variation of growth, chemical content and biofouling of cultivated sugar kelp (Saccharina latissima) along the Norwegian coast. J Appl Phycol 32:2215-2232. https://doi.org/10.1007/s10811-020-02038-y

Fortes MD, Lüning K (1980) Growth rates of North Sea macroalgae in relation to temperature, irradiance and photoperiod. Helgol Meeresunters 34:15-29

Fredriksen R (2018) Epibenthic community structure in the Northeast Greenland and in the Kitikmeot Sea in the Canadian Arctic Archipelago. Master thesis, UiT The Arctic University of Norway

Fredriksen S, Karsten U, Bartsch I, Woelfel J, Koblowsky M, Schumann R, Moy SR, Steneck RS, Wiktor JM, Hop H, Wiencke C (2019) Biodiversity of benthic macro-and microalgae from Svalbard with special focus on Kongsfjorden. In: Hop H, Wiencke $\mathrm{C}$ (eds) The Ecosystem of Kongsfjorden, Svalbard. Advances in Polar Ecology 2, Springer, Cham, pp 331-371

Gavrilo MV, Spiridonov VA, Kosobokova KN, Romanfredenko FA, Krasheninnikov AB, Ezhov AV, Basin AB, Syomin VL, Baranskaya AV Alayutdinov AR, Lugovoi NN, Golubev SV, Solomatov AS, Kuzmin EM (2020) Coastal ecosystem of the Severnaya Zemlya Archipelago, one of the least studied in the Arctic: New data of the expedition 'Open ocean: Arctic Archipelagoes - 2019'. 
Proceedings of VIII Int'1 Conference Marine Research and Education, Moscow 28-31 Oct 2019, Vol 2, Tver Polipress, pp 268-273

Hannah CG, Dupont F, Dunphy M (2009) Polynyas and tidal currents in the Canadian Arctic Archipelago. Arctic 62:83-95

Hepburn CD, Holborow JD, Wing SR, Frew RD, Hurd CL (2007) Exposure to waves enhances the growth rate and nitrogen status of the giant kelp Macrocystis pyrifera. Mar Ecol Progr Ser 339:99-108

Johnsen G, Leu E, Gradinger R (2020). Marine micro-and macroalgae in the polar night. In: Berge J, Johnsen G, Cohen J (eds) Polar night marine ecology. Advances in polar ecology, vol 4. Springer, Cham, pp 67-112. https://doi.org/10.1007/978-3-030-33208-2_4

Karsten U (2007) Research note: salinity tolerance of Arctic kelps from Spitsbergen. Phycol Res 55:257-262

Karsten U, Wiencke C, Kirst GO (1991) The effect of salinity changes upon physiology of eulittoral green macroalgae from Antarctica and Southern Chile. I. Cell viability, growth, photosynthesis and dark respiration. J Plant Physiol 138:667-673

Keck Al-Habahbeh A, Kortsch S, Bluhm BA, Beuchel F, Gulliksen B, Ballantine C, Cristini D, Primicerio R (2020) Arctic coastal benthos long-term response to perturbations under climate warming. Philos T R Soc A 20190355

Konar B, Estes JA (2003) The stability of boundary regions between kelp forests and deforested areas. Ecology 84:174-185

Kortsch S, Primicerio R, Beuchel F, Renaud PE, Rodrigues J, Lønne OJ, Gulliksen B (2012) Climate-driven regime shifts in Arctic marine benthos. P Natl Acad Sci 109:14052-14057

Krause-Jensen D, Marbà N, Olesen B, Sejr MK, Christensen PB, Rodrigues J, Renaud PE, Balsby TJS, Rysgaard S (2012) Seasonal sea ice cover as principal driver of spatial and temporal variation in depth extension and annual production of kelp in Greenland. Glob Change Biol 18:2981-2994

Krause-Jensen D, Lavery P, Serrano O, Marbà N, Masque P, Duarte CM (2018) Sequestration of macroalgal carbon: the elephant in the Blue Carbon room. Biol Letters 14:20180236

Krause-Jensen D, Archambault P, Assis J, Bartsch I, Bischof K, Filbee-Dexter K, Dunton KH, Maximova O, Ragnarsdóttir SB, Sejr MK, Simakova U (2020) Imprint of climate change on pan-Arctic marine vegetation. Front Mar Sci 7:617324. https://doi.org/10. 3389/fmars.2020.617324

Krumhansl K, Scheibling R (2012) Production and fate of kelp detritus. Mar Ecol Prog Ser 467:281-302. https://doi.org/10.3354/meps0 9940

Küpper FC, Peters AF, Shewring DM, Sayer MD, Mystikou A, Brown H, Azzopardi E, Dargent O, Strittmatter M, Brennan D, Asensi AO, van West P, Wilce RT (2016) Arctic marine phytobenthos of northern Baffin Island. J Phycol 52:532-549

Kusumo HT, Druehl LD (2000) Variability over space and time in the genetic structure of the winged kelp Alaria marginata. Mar Biol 136:397-409

Lantuit H, Overduin PP, Couture N, Wetterich S, Aré F, Atkinson D, Brown J, Cherkashov G, Drozdov D, Forbes DL, Graves-Gaylord A, Grigoriev M, Hubbertsen H-H, Jordan J, Jorgenson T, Ødegård RS, Ogorodov S, Pollard WH, Rachold V, Sedenko S, Solomon S, Steehuisen F, Streleskaya I, Vasiliev A (2012) The Arctic coastal dynamics database: a new classification scheme and statistics on Arctic permafrost coastlines. Estuar Coasts 35:383-400

Lippert H, Iken K, Rachor E, Wiencke C (2001) Macrofauna associated with macroalgae in the Kongsfjord (Spitsbergen). Polar Biol 24:512-522

Lüning K (1990) Seaweeds: their environment, biogeography, and ecophysiology. John Wiley \& Sons, New York

Makkar HP, Tran G, Heuzé V, Giger-Reverdin S, Lessire M, Leba F, Ankers P (2016) Seaweeds for livestock diets: a review. Anim Feed Sci Tech 212:1-17
McLaughlin F, Proshutinsky A, Carmack EC, Shimada K, Brown K, Corkum M, Dempsey M, Drost H, Eert J, Green I, Guay C, Hutchings J, Illasiak J, Jackson J, Krishfield R, Li WKW, Maclean H, Nelson J, Newhall K, Nishino S, Ostrom W, Smith J, Steel M, Sutherland N, White L, Yamamoto-Kawai M, Zhao J, Zimmermann S (2012) Physical, chemical and zooplankton data from the Canada Basin and Canadian Arctic Archipelago, Jul 20 to Sep 14, 2006. Can Data Rep Hydrogr Ocean Sci 186: x + 373 p.

Muth AF, Bonsell C, Dunton KH (2021) Inherent tolerance of extreme seasonal variability in light and salinity in an Arctic endemic kelp (Laminaria solidungula). J Phycol 57:1554-1562

Nelson RJ, Young KV, Williams WJ (2019) Marine zooplankton of Coronation Gulf and Bathurst Inlet, Nunavut. Canada. Cont Shelf Res 191:104003

Niemi A, Ferguson S, Hedges K, Melling H, Michel C, Ayles B, Azetsu-Scott K, Coupel P, Deslauriers D, Devred E, Doniol-Valcroze T, Dunmall K, Eert J, Galbraith P, Geoffroy M, Gilchrist G, Hennin H, Howland K, Kendall M, Kohlbach D, Lea E, Loseto L, Majewski A, Marcoux M, Matthews C, McNicholl D, Mosnier A, Mundy CJ, Ogloff W, Perrie W, Richards C, Richardson E, Reist R, Roy V, Sawatzky C, Scharffenberg K, Tallman R, Tremblay J-É, Tufts T, Watt C, Williams W, Worden E, Yurkowski D, Zimmerman S (2019) State of Canada's Arctic Seas. Can Tech Rep Fish Aquat Sci 3344: xv + 189 p

Norderhaug KM, Christie H, Fosså JH, Fredriksen S (2005) Fishmacrofauna interactions in a kelp (Laminaria hyperborea) forest. J Mar Biol Assoc UK 85:1279

Norderhaug KM, Christie HC (2009) Sea urchin grazing and kelp revegetation in the NE Atlantic. Mar Biol Res 5-6:515-528. https:// doi.org/10.1080/17451000902932985

Nunavut Coastal Resource Inventory Cambridge Bay (2015) Dept. of Environment, Iqualiut, Nunavut

Orland C, Queirós AM, Spicer JI, McNeill CL, Higgins S, Goldworthy S, Zananiri T, Archer L, Widdicombe S (2016) Application of computer-aided tomography techniques to visualize kelp holdfast structure reveals the importance of habitat complexity for supporting marine biodiversity. J Exp Mar Biol Ecol 477:47-56

Parks Canada (2019) https://www.youtube.com/watch?v=OxyTZ 3F7mkA. Accessed Oct 2021

Pedersen MF, Filbee-Dexter K, Norderhaug KM, Fredriksen S, Frisk NL, Wernberg T (2020) Detrital carbon production and export in high latitude kelp forests. Oecologia 192:227-239

Rotermund LM, Williams WJ, Klymak JM, Wu Y, Scharien RK, Haas C (2021) The effect of sea ice on tidal propagation in the Kitikmeot Sea, Canadian Arctic Archipelago. J Geophys Res. https:// doi.org/10.1029/2020JC016786

Renaud PE, Lokken TS, Jorgensen LL, Berge J, Johnson BJ (2015) Macroalgal detritus and food-web subsidies along an Arctic fjord depth-gradient. Front Mar Sci 2:31. https://doi.org/10.3389/fmars. 2015.00031

Roleda MY (2009) Photosynthetic response of Arctic kelp zoospores exposed to radiation and thermal stress. Photoch Photobiol Sci 8:1302-1312

Roy V, Iken K, Archambault P (2014) Environmental drivers of the Canadian Arctic megabenthic communities. PLoS ONE 9(7):e100900

Scherrer KJN, Kortsch S, Varpe Ø, Weyhenmeyer GA, Gulliksen B, Primicerio R (2019) Mechanistic model identifies increasing light availability due to sea ice reductions as cause for increasing macroalgae cover in the Arctic. Limnol Oceanogr 64:330-341

Schultz J, Heywood J, Gibbs D, Borden L, Kent D, Neale M, Kulcsar C, Banwait R, Trethewey L (2018) Arctic marine ecology benchmarking program: monitoring biodiversity using SCUBA. Polar Knowledge 1:39-45 
Schuster M, Konar B (2014) Foliose algal assemblages and deforested barren areas: phlorotannin content, sea urchin grazing and holdfast community structure in the Aleutian dragon kelp, Eualaria fistulosa. Mar Biol 161:2319-2332

Silber GK, Adams JD (2019) Vessel operations in the Arctic, 20152017. Front Mar Sci 6:573

Sivertsen K (1997) Geographic and environmental factors affecting the distribution of kelp beds and barren grounds and changes in biota associated with kelp reduction at sites along the Norwegian coast. Can J Fish Aquat Sci 54:2872-2887

Sou T, Flato G (2009) Sea ice in the Canadian Arctic Archipelago: Modeling the past (1950-2004) and the future (2041-60). J Climate 22:2181-2198

Steneck R, Graham M, Bourque BJ, Corbett D, Erlandson JM, Estes JA, Tegner MJ (2002) Kelp forest ecosystems: Biodiversity, stability, resilience and future. Environ Conserv 29:436-459

tom Dieck (Bartsch) I (1992) North Pacific and North Atlantic digitate Laminaria species (Phaeophyta): hybridization experiments and temperature responses. Phycologia 31:147-163. https://doi.org/ 10.2216/i0031-8884-31-2-147.1

Wernberg T, Filbee-Dexter K (2018) Grazers extend blue carbon transfer by slowing sinking speeds of kelp detritus. Sci Rep-UK 8(1): $1-7$

Wiencke C, Amsler C (2012) Seaweeds and their communities in polar regions. Chapter 13. In: Wiencke C, Bischof K (eds) Seaweed
Biology. Ecological Studies 219, Springer-Verlag Berlin Heidelberg 2012, pp 265-291. https://doi.org/10.1007/978-3-642-284519_13

Wilce RT (1994) The Arctic subtidal as a habitat for macrophytes. In: Lobban CS, Harrison PJ (eds) Seaweed ecology and physiology. Cambridge University Press, Cambridge, pp 89-92

Wilce RT, Dunton KH (2014) The Boulder Patch (North Alaska, Beaufort Sea) and its benthic algal flora. Arctic 67:43-56

Wilce RT (2016) The "Arctic Stamp", its imprint on an endangered marine flora. Perspectives Phycol 3:155-180

Williams W, Brown KA, Bluhm B, Carmack EC, Dalman L, Danielson SL, Else BGT, Fredriksen R, Mundy CJ, Rotermund LM, Schimnowski A (2018) Stratification in the Canadian Arctic Archipelago's Kitikmeot Sea: biological and geochemical consequences. Polar Knowledge 1:46-52

Wilson KL, Skinner MA, Lotze HK (2019) Projected 21st-century distribution of canopy-forming seaweeds in the Northwest Atlantic with climate change. Divers Distrib 25:582-602

Publisher's Note Springer Nature remains neutral with regard to jurisdictional claims in published maps and institutional affiliations. 